\title{
Application of treated domestic sewage effluent on the quality indicators of an Oxisol cultivated with castor bean ${ }^{1}$
}

\author{
Adailton Conceição dos Santos ${ }^{2}$, Cácio Luiz Boechat ${ }^{3 *} \mathbb{D}$, Paloma Cunha Saraiva ${ }^{3}$, \\ Adriana Miranda de Santana Arauco ${ }^{3}$, Felizardo Adenilson Rocha ${ }^{4}$, Maria de Fátima da Silva Pinto Peixoto ${ }^{2}$
}

10.1590/0034-737X201966020001

\begin{abstract}
In semi-arid regions of developing countries worldwide it is necessary to develop low cost technology methods to acquire new water supplies. The objective was to evaluate the changes in the attributes of soil quality irrigated with treated sewage effluent. The treatments consisted of applying treated sewage effluent (TSE) and underground well water (UWW) in the following proportions: $\mathrm{E}_{0 \%}$ (chemical fertilization and UWW), $\mathrm{E}_{25 \%}\left(25 \%\right.$ TSE and $75 \% \mathrm{UWW}$ ), $\mathrm{E}_{50 \%}$ (50\% of TSE and UWW), $\mathrm{E}_{75 \%}$ (75\% TSE and 25\% UWW) and $\mathrm{E}_{100 \%}$ (100\% TSE). The sodium content did not differ significantly among the treatments, but the sodium input diminished as the percentage of residuary water in the irrigation grew. There was a greater increment of microbial biomass carbon in the $\mathrm{E}_{25 \%}$ treatment. On the other hand, although treatments $\mathrm{E}_{50 \%}$ to $\mathrm{E}_{100 \%}$ have a greater nutrient input, they were no different from control treatments performed with well water. Treated domestic sewage effluent at a proportion of $25 \%$ is a feasible alternative for castor bean irrigation, however it is necessary to monitor the possible changes in the soil attributes over successive crops. Microbial attributes can be used as a quick, good indicator of changes in soil quality.
\end{abstract}

Keywords: Water reuse; Electrical conductivity; Chemical attributes; Physical attributes; Microbial attributes.

\section{INTRODUCTION}

A priority challenge in the 21 st century is the increased need for food production while maintaining sustainable agriculture (Braga \& Lima, 2014). Agriculture is one of the activities responsible for about $70 \%$ of the total water consumption worldwide. This use must be reduced by introducing appropriate technologies, eliminating waste and introducing reuse and recycling. Water reuse offers economic, environmental and social possibilities and may become necessary in situations of scarcity to meet the water demand (Gloaguen et al., 2010).

The use of residuary water in agriculture aims to promote sustainability of irrigated agriculture, since it spares non-polluted surface waters, maintaining environmental quality and providing a source of plant nutrition (Barbosa et al., 2018).
Agricultural production in the arid and semiarid regions is characterized by excessive evapotranspiration instead of precipitation throughout most of the year. Therefore, agriculture in these regions depends on supplementary irrigation to enable crop growth and, at the same time, one of the main environmental problems in these regions is scarce freshwater (Molahoseini, 2014).

Reuse for the cultivation of castor beans (Ricinus communis L.) may provide an incentive to the National Program of Production and Use of Biodiesel (PNPB - Programa Nacional de Produção e Uso do Biodiesel) which aims at the technical and economically sustainable implementation of the production and use of biodiesel (Souza et al., 2010). It is also an alternative to family agriculture (Simões et al., 2013).

Research has proved the importance of irrigation using domestic sewage effluents to partly supply some of the

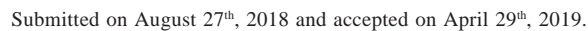

${ }^{2}$ This work is part of the master's thesis of the first author.

${ }^{2}$ Universidade Federal do Recôncavo da Bahia, Cruz das Almas, Bahia, Brazil. agape 323@hotmail.com; fatima@ufrb.edu.br

${ }^{3}$ Universidade Federal do Piauí, Bom Jesus, Piauí, Brazil. cacioboechat@gmail.com; paloma-saraiva31@hotmail.com; adrianamsarauco@gmail.com

${ }^{4}$ Instituto Federal da Bahia, Vitória da Conquista, Bahia, Brazil. felizardoar@hotmail.com

*Corresponding author: cacioboechat@gmail.com
} 
elements, mainly nitrogen, phosphorus and potassium, required by the crops, which increases agricultural yields (Molahoseini, 2014). However, due to the physicochemical properties of domestic sewage, it is necessary to identify the effects of this irrigation practice on the quality of soil because it may change the soil attributes and quality (Costa, 2014) and could limit crop development and yields (Barbosa et al., 2018).

The soil quality indicators are important both for nutrient cycling and to estimate the soil capacity for plant growth. They also allow characterizing, evaluating and following the changes that occur in a certain ecosystem (Araújo et al., 2012). Given the reasons above, this study aimed to evaluate the effect of the application of sewage effluent on the chemical, physical and biological attributes of an Oxisol Ustox in which castor beans are cultivated.

\section{MATERIAL AND METHODS}

\section{Characterization of the area}

The field study was performed in an experimental area located in the municipality of Cruz das Almas - BA, at the following coordinates: $12^{\circ} 40^{\prime} 12^{\prime \prime} \mathrm{S}$ and $39^{\circ} 06^{\prime} 07^{\prime \prime} \mathrm{W}$. The climate according to the Köppen classification is of the Af type, warm, with minimum temperatures in the coldest months higher than $18{ }^{\circ} \mathrm{C}$ and a mean of $24.2{ }^{\circ} \mathrm{C}$ and a mean precipitation of $1200 \mathrm{~mm}$, with a variation between 900 and $1300 \mathrm{~mm}$, distributed over two well-defined seasons: the wet period (March-August) with $63 \%$ of annual pluviosity, and the dry period (SeptemberFebruary).

Data on precipitation, temperature and relative air humidity during the time of the experiment are shown in Figure 1.
The soil was classified as Oxisol Ustox (Soil Survey Staff, 2014) or "Latossolo Amarelo distrocoeso", according to the Brazilian System of Soil Classification (Santos et al., 2018). About twenty-five simple samples were collected in the area at a depth of $0.00-0.20 \mathrm{~m}$ to form composite samples that were air-dried, sieved with a 2.0 $\mathrm{mm}$ mesh, homogenized and characterized chemically.

Undeformed samples were also collected with the help of volumetric rings in minitrenches for physico-chemical characterization according to Embrapa (2009), and thus represent the initial condition of the soil $\left(\mathrm{C}_{0}\right): 4.9 \mathrm{pH}_{\mathrm{H} 2 \mathrm{O}}$; $16.0 \mathrm{mg} \mathrm{dm}^{-3} \mathrm{P} ; 0.12 \mathrm{cmol}_{\mathrm{c}} \mathrm{dm}^{-3}$ to $\mathrm{K}^{+}, 1.8 \mathrm{cmol}_{\mathrm{c}} \mathrm{dm}^{-3}$ to $\mathrm{Ca}^{+2}+\mathrm{Mg}^{+2}, 0.1 \mathrm{cmol}_{\mathrm{c}} \mathrm{dm}^{-3}$ to $\mathrm{Na}^{+}, 2.2 \mathrm{cmol}_{\mathrm{c}} \mathrm{dm}^{-3}$ sum of exchangeable bases, $5.0 \mathrm{cmol}_{\mathrm{c}} \mathrm{dm}^{-3}$ to cationic exchange capacity to $\mathrm{pH} 7.0$ and $3.0 \mathrm{cmol}_{\mathrm{c}} \mathrm{dm}^{-3}$ to $\mathrm{H}+\mathrm{Al} ; 40.0 \%$ based saturation index and $2.0 \%$ percentage of exchangeable sodium; 0.01 (meq $\left.\mathrm{L}^{-1}\right)^{0,5}$ sodium adsorption ratio; $0.12 \mathrm{dS} \mathrm{m}^{-1}$ electrical conductivity; $10.7 \mathrm{~g} \mathrm{~kg}^{-1}$ organic matter; $33.4 \mathrm{~cm}^{3} \mathrm{~cm}^{-3}$ total pore volume; $1.6 \mathrm{~g} \mathrm{~cm}^{-3}$ soil bulk density; $79.0 \mathrm{~cm} \mathrm{~h}^{-1}$ hydraulic conductivity; $50.9 \%$ to macroporosity, $48.3 \%$ to microporosity and $11.5 \%$ to water-dispersed clay; $703 \mathrm{~g} \mathrm{~kg}^{-1}$ sand, $76 \mathrm{~g} \mathrm{~kg}^{-1}$ silt and $221 \mathrm{~g} \mathrm{~kg}^{-1}$ clay.

Liming was performed based on the chemical analysis of soil using the base saturation method (60\%), according to the Minas Gerais state recommendations for the use of amendments and fertilizers (CFSEMG, 1999). Liming was performed three months before the experiment was set up with a single application of $1.2 \mathrm{tha}^{-1}$ of dolomitic limestone and incorporation up to $0.20 \mathrm{~m}$.

The treated sewage effluent (TSE) was obtained from the water and sewage treatment plant in the municipality of Cachoeira - BA. The treated effluent was collected in

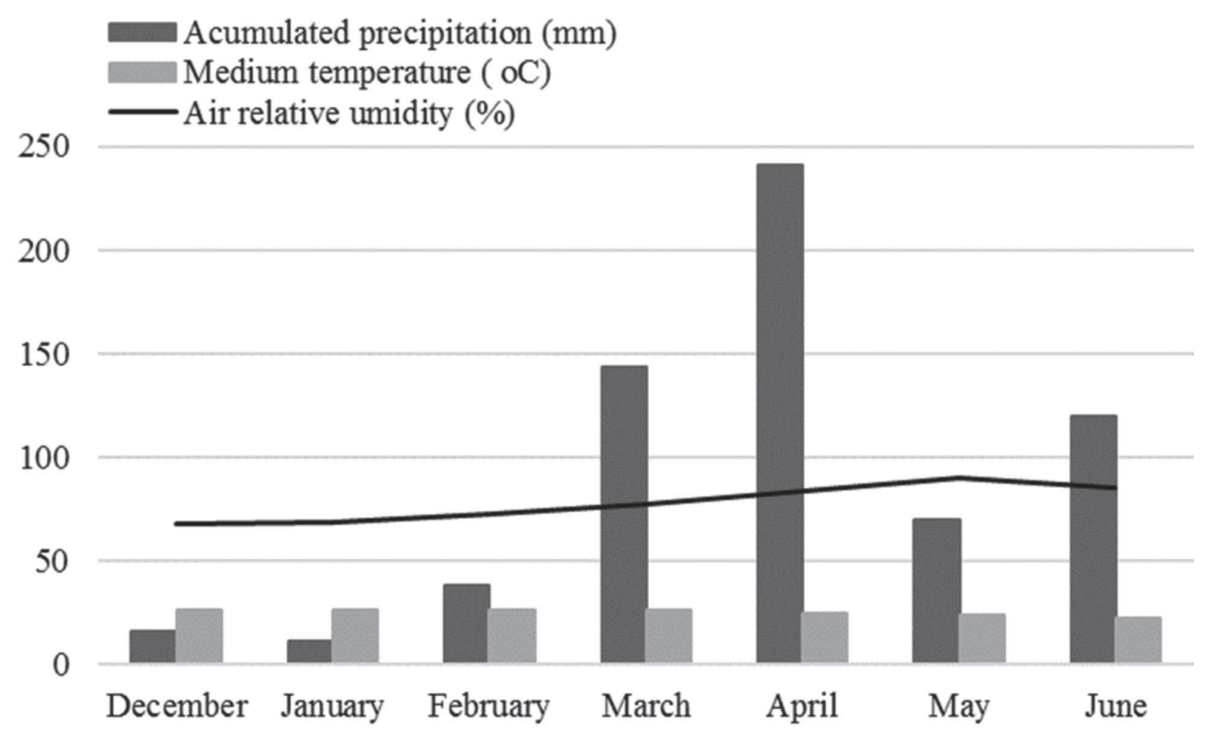

Figure 1: Mean behavior of the monthly climate variables analyzed during the experiment.

Rev. Ceres, Viçosa, v. 66, n.2, p. 077-084, mar/abr, 2019 
the drippers, stored at a temperature of $-2 \pm 1^{\circ} \mathrm{C}$ for later chemical characterization. The water utilized to dilute TSE was from an underground well and samples were collected at the end of each month and analyzed according to a proposal by APHA (1995). Table 1 shows the chemical characteristics of the treated sewage effluent and well water.

\section{Field experiment}

The treatments were arranged in a casualized block design and consisted of applying proportions of the mixture of treated sewage effluent (TSE) and underground well water (UWW), with four replicates, as follows: $\mathrm{E}_{0 \%}$ (conventional management with chemical fertilization recommended for crops and irrigated with UWW), $\mathrm{E}_{25 \%}$ (25\% TSE and 75\% UWW), $\mathrm{E}_{50 \%}(50 \%$ TSE and 50\% UWW), $\mathrm{E}_{75 \%}(75 \% \mathrm{TSE}$ and $25 \% \mathrm{UWW})$ and $\mathrm{E}_{100 \%}(100 \%$ TSE). Table 2 shows the quantities of $\mathrm{P}, \mathrm{N}, \mathrm{K}, \mathrm{Ca}, \mathrm{Mg}$ and $\mathrm{Na}$, applied to the soil $\left(\mathrm{kg} \mathrm{ha}^{-1}\right)$ by an irrigation system in each treatment.

In the treatment with conventional management $\left(\mathrm{E}_{0 \%}\right)$ $50 \mathrm{~kg} \mathrm{ha}^{-1}$ of $\mathrm{N}\left(10 \mathrm{~kg} \mathrm{ha}^{-1}\right.$ in planting and $40 \mathrm{~kg} \mathrm{ha}^{-1}$ as a top dressing), $50 \mathrm{~kg} \mathrm{ha}^{-1}$ of $\mathrm{P}_{2} \mathrm{O}_{5}$ and $25 \mathrm{~kg} \mathrm{ha}^{-1}$ of $\mathrm{K}_{2} \mathrm{O}$ were applied. The sources of N, P and K used were urea, simple superphosphate and potassium chloride, respectively.
The criteria adopted to define the levels of irrigation were based on evapotranspiration from the castor bean crop and, to estimate the water needs of the crop a Class A Tank, a rain gauge and automatic meteorological station were installed to monitor the meteorological conditions. The frequency of application of the treatment with a twoday watering shift and a uniformity test of water application from the drippers were performed monthly to ensure the efficiency of the application system.

The experimental plots occupied a $16 \mathrm{~m}^{2}$ area where a dwarf variety of castor beans was planted, early (first cycle of approximately 120 days,) EBDA MPB 01 variety, sown with a spacing of $1.0 \times 0.5 \mathrm{~m}$, in each of the 8 lines, using 3 seeds per hole. Approximately 30 days after planting, thinning out was performed manually, leaving the plant that was visually most vigorous per hole.

\section{Chemical and physical changes}

Soil samples were collected at a depth of 0.00 to $0.20 \mathrm{~m}$ at the beginning and end of the cultivation cycle, and this was done in each experimental plot, parallel to the planting line, on both sides, at a distance of approximately 0.10 in the plant row, totalizing eight simple samples, to form a composite sample. The samples were air dried, sieved through a 2.0 mesh, homogenized and stored for later

Table 1: Physico-chemical characteristics of underground well water (UWW), treated sewage effluent (TSE) and mean reference value for treated sewage (MRVTS)

\begin{tabular}{|c|c|c|c|c|c|c|c|c|c|}
\hline \multirow{2}{*}{ Solution } & \multirow[t]{2}{*}{ pH } & $\mathrm{Ca}^{+2}+\mathrm{Mg}^{+2}$ & $\mathbf{K}^{+}$ & $\mathbf{N a}^{+}$ & TSS & $\mathbf{P}$ & total-N & $\mathrm{Cl}^{-}$ & \multirow{2}{*}{$\mathrm{HCO}_{3}^{-}$} \\
\hline & & \multicolumn{7}{|c|}{$m g L^{-1}$} & \\
\hline UWW & 7.5 & 392.7 & 16.0 & 56.0 & 1050.8 & 0.10 & 24.9 & 812.9 & 922.5 \\
\hline TSE & 6.5 & 165.4 & 51.0 & 140.0 & 2160.8 & 15.9 & 60.0 & 48.0 & 1698.5 \\
\hline \multirow[t]{3}{*}{ MRVTS $^{1,2}$} & $6.8-7.3$ & $30-170$ & $10-40$ & $50-250$ & $400-1200$ & $4.2-9.7$ & $10-50$ & $40-200$ & $\ldots .$. \\
\hline & BOD & COD & OC & EC & TC & TT & SAR & $\begin{array}{c}\mathrm{Ca} / \mathrm{Mg} \\
\text { ratio }\end{array}$ & $\begin{array}{c}\text { BOD } / C O D \\
\text { ratio }\end{array}$ \\
\hline & & $\mathbf{m g ~ L ^ { - 1 }}$ & & $\mathrm{dS} \mathrm{m}^{-1}$ & \multicolumn{2}{|c|}{ NMP $100 \mathrm{~mL}^{-1}$} & $\left(\mathrm{mmol} \mathrm{L} \mathbf{L}^{-1}\right)^{0.5}$ & & \\
\hline UWW & 6.7 & 10.0 & 46.0 & 1.4 & $1.5 \times 10^{2}$ & $<1.0$ & 1.4 & 0.76 & 0.65 \\
\hline TSE & 155.0 & 269.0 & 138.0 & 2.9 & $1.3 \times 10^{6}$ & $<1.0$ & 4.5 & 1.1 & 0.58 \\
\hline MRVTS $^{1,2}$ & $10-80$ & $30-60$ & $\ldots .$. & $1.0-3.1$ & $\ldots .$. & & $4.5-7.9$ & $\ldots .$. & 2.4 \\
\hline
\end{tabular}

TSS - total suspended solids; $\mathrm{P}$ - available phosphorus; OC - organic carbon; $\left(\mathrm{K}+, \mathrm{Ca}^{+2}\right.$ and $\left.\mathrm{Mg}^{+2}\right)$ - potassium, calcium and exchangeable magnesium, respectively; PES - percentage of exchangeable sodium; SAR - sodium adsorption ratio; EC - electrical conductivity of soil; BOD - biochemical oxygen demand; COD - chemical oxygen demand; TC - total coliforms; TT - thermotolerant coliforms (Fecal - E. coli); SAR - Sodium adsorption ratio; ${ }^{1}$ Pescod (1992); ${ }^{2}$ Feigin et al. (1991).

Table 2: Treatments with an input of nutrients and sodium into soil using irrigation water.

\begin{tabular}{|c|c|c|c|c|c|c|}
\hline \multirow{2}{*}{ Treatment } & total-N & total-P & $\mathbf{K}^{+}$ & $\mathrm{Ca}^{2+}$ & $\mathrm{Mg}^{2+}$ & \multirow{2}{*}{$\mathrm{Na}^{+}$} \\
\hline & \multicolumn{5}{|c|}{$\mathrm{kg} \mathrm{ha}^{-1}$} & \\
\hline $\mathrm{E}_{0 \%}$ & 67 & 0,3 & 35 & 459 & 602 & 151 \\
\hline $\mathrm{E}_{25 \%}$ & 91 & 11 & 67 & 403 & 504 & 208 \\
\hline $\mathrm{E}_{50 \%}$ & 115 & 22 & 58 & 346 & 407 & 265 \\
\hline $\mathrm{E}_{75 \%}$ & 138 & 32 & 70 & 290 & 310 & 321 \\
\hline $\mathrm{E}_{100 \%}$ & 162 & 43 & 81 & 234 & 213 & 378 \\
\hline
\end{tabular}


chemical and physical characterization according to the methodology described in Embrapa (2009).

\section{Microbiological activity and biomass}

Soil samples used in the experiment were collected at a depth of $0.20 \mathrm{~m}$, sieved through a $2 \mathrm{~mm}$ mesh and, homogenized. The microbial incubation was conducted at a controlled temperature of $28 \pm 2{ }^{\circ} \mathrm{C}$ and humidity near $70 \%$ of the field capacity using a BOD incubator in the absence of light.

The soil basal respiration $\left(\mathrm{C}-\mathrm{CO}_{2}\right)$ was determined by incubating $100 \mathrm{~g}$ soil (dry weight) with the treatments in plastic bottles, placed on the surface of respirometric glass pots with a tightly sealed screw cap. A second pot containing $30 \mathrm{ml}$ of $1 \mathrm{Mol} \mathrm{L}^{-1} \mathrm{NaOH}$ solution was added for the capture of $\mathrm{CO}_{2}$ and another containing $30 \mathrm{ml}$ of distilled water in order to keep the internal moisture constant.

After 7 days of incubation, accumulated $\mathrm{C}-\mathrm{CO}_{2}$ was withdrawn from the bottle with a solution of $\mathrm{NaOH}$ and added to $10 \mathrm{~mL}$ of $0.5 \mathrm{~mol} \mathrm{~L}^{-1} \mathrm{BaCl}_{2}$ and 3 drops of phenolphthalein indicator at $1 \%$. The amount of $\mathrm{CO}_{2}$ released from the soil was determined by titration of excess $\mathrm{NaOH}$ with $0.025 \mathrm{Mol} \mathrm{L}^{-1} \mathrm{HCl}$ solution.

The microbial biomass carbon was determined by the method described by Vance et al. (1987) using, instead of chloroform, the microwave irradiation technique proposed by Ferreira et al. (1999) in order to kill the microorganisms and trigger the release of cellular components.

A solution of $\mathrm{K}_{2} \mathrm{SO}_{4} 0.5 \mathrm{Mol} \mathrm{L}^{-1}$ (soil:extractant $=1: 4$ ) was added to the radiated and non- radiated soils followed by horizontal circular shaking at $220 \mathrm{rpm}$ for 30 $\min$. The extracts remained at rest for another 30 minutes and were filtered through Whatman ${ }^{\circledR} \mathrm{n}^{\circ} 42$ filter paper (diameter $7 \mathrm{~cm}$ ). The microbial biomass carbon $\left(\mathrm{C}_{\text {mic }}\right)$ contents in extracts were determined by the wet combustion method (Tedesco et al., 1995).

The metabolic quotient $\left(\mathrm{qCO}_{2}\right)$ was calculated as the ratio between soil basal respiration rate and microbial biomass $\mathrm{C}$ and expressed as $\mathrm{mg} \mathrm{CO}_{2} \mathrm{~g}^{-1} \mathrm{C}_{\min } \mathrm{h}^{-1}$.

\section{Statistical analysis}

Data were subjected to the $\mathrm{F}$ test by analysis of variance (ANOVA). The Scott-Knott's test at a significance level of $p<0.05$ was used to compare mean values for each variable studied. The Sisvar program was used to analyze the data (Ferreira, 2011).

\section{RESULTS AND DISCUSSION}

Was evaluated the effect of sewage effluent levels on the chemical, physical and microbiological attributes of soil in the castor bean crop and changes were observed in these attributes of soil quality (Tables 3, 4 and 5). The variable soil $\mathrm{pH}$ was significantly diminished only in treatment E25, and there was no difference in the other treatments (Table 3 ). However, the $\mathrm{pH}$ values continue to be appropriate for good plant growth (CFSEMG, 1999). In soil the diminished $\mathrm{pH}$ can be associated with the nitrification reactions of ammoniacal N, with the probable oxidation of sulfites and with the production of organic acids during the degradation of the residues by microorganisms (Simonete et al., 2003).

Andrade Filho et al. (2013) observed contrary effects, showing a slight increase of $\mathrm{pH}$ when using residuary waste water on Oxisol and Inceptisol, and this increase was attributed to the basic $\mathrm{pH}$ of the effluent and increase of cations in soils.

There was no significant difference in the $\mathrm{Ca}^{2+}$ and $\mathrm{Mg}^{2+}$ contents of soil in the treatments evaluated (Table $3)$. However, the input of these elements to the soil decreased according to the increase of effluent in the mix since the concentrations of calcium and magnesium are higher in well water (Tables 3 and 4). The contents observed could be related to the concentration absorbed by the plants. However, they are numerically greater than the initial condition of the soil $\left(\mathrm{C}_{0}\right)$.

Similarly, although the input of potassium (K) increases with the increased percentage of effluent in the mix (Table 2), this effect was not observed in soil, the highest concentration being observed in treatment with the fertilization of the foundation $\left(\mathrm{E}_{0 \%}\right)$ (Table 3). However, the reduction of this element in soil was observed in relation to the initial condition of the soil $\left(\mathrm{C}_{0}\right)$, with $\mathrm{K}$ values considered low (CFSEMG, 1999). This result may be related to the export of the element by the crop or its leaching in the soil profile.

The sodium (Na) content did not differ significantly among the treatments, but the sodium input diminished as the percentage of residuary water in the irrigation grew (Table 2). Probably the low exchangeable Na contents in the soil are the result of a short period of treated effluent deposition in the area and, may also be related to the leaching of this cation in the soil profile with the rainwater.

High Na contents are limiting factors for the use of treated effluent in agriculture, since this element may replace calcium and magnesium in the exchange complex, dispersing the clay, destroying the aggregates and the structure of the soils and reducing permeability and water infiltration by dispersing the colloids and subsequent macropore clogging (Erthal et al., 2010).

The values observed for the sum of bases (SB) were lower in the treatments using residuary water and the highest value in the EO\% treatment (Table 3). This value $\left(3.20 \mathrm{cmol}_{\mathrm{c}} \mathrm{dm}^{-3}\right)$ may be related to the higher concentrations of calcium, potassium and sodium in the 
$\mathrm{E}_{0 \%}$ treatment. According to CFSEMG (1999) the values found in the treatments are considered average.

The values observed for the variable base saturation (V) were higher in the $\mathrm{E}_{0 \%}, \mathrm{E}_{25 \%}$ and $\mathrm{E}_{50 \%}$ treatments (Table 3). In all treatments the soils could be considered fertile (eutrophic), enabling crop growth. In general, the increases in CEC and in base saturation by applying residuary waters are attributed to the high concentration of ions and to the organic colloids present in the effluents (Erthal et al., 2010).

The available phosphorus $(\mathrm{P})$ contents observed in the treatments varied from 2.0 to $18.0 \mathrm{mg} \mathrm{dm}^{-3}$. The treatment with the recommended commercial fertilizer $\left(\mathrm{E}_{0 \%}\right)$ presented the highest value, followed by treatments $\mathrm{E}_{75 \%}$ and $\mathrm{E}_{100 \%}$ with the lowest values at $\mathrm{E}_{25 \%}$ and $\mathrm{E}_{50 \%}$ (Table 3). The highest proportions of the effluent increased the $\mathrm{P}$ content in the soil due to the input of the element (Table 2 ), but these values were lower than observed at $\mathrm{E}_{0 \%}$.

Organic matter $(\mathrm{OM})$ is indicated as the cause of reduction in the adsorption of $\mathrm{P}$ in soil due to the anionic character of the products of their decomposition (humic and fulvic acids, and others), which bind to the $\mathrm{P}$ adsorption sites and increase the availability of this element in soil (Costa et al., 2014). Therefore, the use of effluent is a good option to input $\mathrm{P}$ into the soil, but it is necessary to perform a complementation in the mineral form (Erthal et al., 2010).

There was no significant effect of the treatment on the potential soil acidity $(\mathrm{H}+\mathrm{Al})$ (Table 3 ). However, Barreto et al. (2013) observed a reduction of potential acidity in the plots supplied with residuary water, besides additions to the concentrations of $\mathrm{Ca}^{2+}$ and $\mathrm{Mg}^{2+}$.

As to $\mathrm{CEC}_{\mathrm{T}}$ the values observed in the $\mathrm{E}_{0 \%}$ treatment were significantly higher than those observed in the other treatments (Table 3). It can be verified that like the increase of the sum of bases (Table 3 ) there were increments due to the addition of exchangeable cations provided by the liming, and no effect of the input of cations via residuary water in irrigation was observed (Table 2).

The sodium saturation (PES) variable which represents the proportion of these cations in relation to the cationic exchange capacity, used as a criterion in the classification of soils affected by salts, presented higher values for $\mathrm{E}_{50 \%}$ and $\mathrm{E}_{75 \%}$ (Table 3). The increased PES leads to the reduction of the availability of exchangeable potassium, phosphorus and magnesium (Garcia et al., 2008), besides the decline in the physical properties of soil, clogged pores and, sometimes diminished permeability of the soil, bad performance of the plant, diminished leaching and salinization (Varallo et al., 2010).

As to the sodium adsorption ratio (SAR), the value observed in $\mathrm{E}_{50 \%}$ was significantly higher than those observed in the other treatments (Table 3). The increased quantity of salts such as sodium may contaminate the water table and lead to loss of fertility and susceptibility to erosion, besides contamination of the groundwater (Gheyi et al., 2010). Regarding electrical conductivity (EC), there was an increase in values around the doses (Table 3 ), with $\mathrm{E}_{75 \%}$ and $\mathrm{E}_{100 \%}$ presenting the highest values,

Table 3: Chemical alterations of the soil in response to the application of residuary water from treated domestic sewage

\begin{tabular}{|c|c|c|c|c|c|c|c|}
\hline \multirow{2}{*}{ Treatment } & 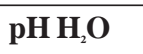 & $\mathrm{Ca}^{+2}$ & $\mathrm{Mg}^{2+}$ & $\mathbf{K}^{+}$ & $\mathrm{Na}^{+}$ & SB & $\mathbf{V}$ \\
\hline & \multicolumn{6}{|c|}{$\mathrm{cmol}_{\mathrm{c}} \mathrm{dm}^{-3}$} & $\%$ \\
\hline$\overline{\mathrm{E}_{0 \%}}$ & $6.1 \mathrm{a}$ & $2.06^{\mathrm{ns}}$ & $1.0^{\mathrm{ns}}$ & $0.10 \mathrm{a}$ & $0.04^{\mathrm{ns}}$ & $3.20 \mathrm{a}$ & $61.5 \mathrm{a}$ \\
\hline $\mathrm{E}_{25 \%}$ & $5.6 \mathrm{~b}$ & 1.82 & 1.0 & $0.07 \mathrm{~b}$ & 0.01 & $2.90 \mathrm{~b}$ & $60.2 \mathrm{a}$ \\
\hline $\mathrm{E}_{50 \%}$ & $6.0 \mathrm{ab}$ & 1.92 & 1.0 & $0.07 \mathrm{~b}$ & 0.01 & $3.00 \mathrm{~b}$ & $60.7 \mathrm{a}$ \\
\hline $\mathrm{E}_{75 \%}$ & $5.9 \mathrm{ab}$ & 1.82 & 1.0 & $0.07 \mathrm{~b}$ & 0.01 & $2.90 \mathrm{~b}$ & $59.1 \mathrm{~b}$ \\
\hline $\mathrm{E}_{100 \%}$ & $5.8 \mathrm{ab}$ & 1.71 & 1.0 & $0.07 \mathrm{~b}$ & 0.02 & $2.80 \mathrm{~b}$ & $57.1 \mathrm{~b}$ \\
\hline $\begin{array}{l}\text { C.V. } \\
\text {. }\end{array}$ & 8.52 & 34.72 & 27.97 & 21.89 & 19.43 & 26.38 & 20.50 \\
\hline \multirow{2}{*}{ Treatment } & $\mathbf{P}$ & $\mathbf{H}+\mathbf{A l}$ & $\mathrm{CEC}_{\mathrm{T}}$ & PES & SAR & $\operatorname{EC}(1: 1)$ & OM \\
\hline & $\mathrm{mg} \mathrm{dm}^{-3}$ & \multicolumn{2}{|c|}{$\mathrm{cmol}_{\mathrm{c}} \mathrm{dm}^{-3}$} & \multicolumn{2}{|c|}{$\left(\operatorname{meq} \mathrm{L}^{-1}\right)^{0.5}$} & $\mathrm{dS} \mathrm{m}^{-1}$ & $\mathrm{~g} \mathrm{~kg}^{-1}$ \\
\hline $\mathrm{E}_{0 \%}$ & $18.0 \mathrm{a}$ & $2.0^{\mathrm{ns}}$ & $5.2 \mathrm{a}$ & $2.0 \mathrm{~b}$ & $1.2 \mathrm{~b}$ & $0.16 \mathrm{c}$ & $14.0 \mathrm{~b}$ \\
\hline $\mathrm{E}_{25 \%}$ & $2.0 \mathrm{~d}$ & 1.92 & $4.8 \mathrm{~b}$ & $2.3 \mathrm{~b}$ & $1.2 \mathrm{~b}$ & $0.21 \mathrm{~b}$ & $15.0 \mathrm{~b}$ \\
\hline $\mathrm{E}_{50 \%}$ & $2.5 \mathrm{~d}$ & 1.95 & $4.9 \mathrm{~b}$ & $2.5 \mathrm{a}$ & $1.3 \mathrm{a}$ & $0.21 \mathrm{~b}$ & $15.8 \mathrm{a}$ \\
\hline $\mathrm{E}_{75 \%}$ & $3.8 \mathrm{~b}$ & 2.0 & $4.9 \mathrm{~b}$ & $2.4 \mathrm{a}$ & $1.1 \mathrm{~b}$ & $0.23 \mathrm{a}$ & $16.0 \mathrm{a}$ \\
\hline $\mathrm{E}_{100 \%}$ & $3.0 \mathrm{c}$ & 2.1 & $4.9 \mathrm{~b}$ & $2.1 \mathrm{~b}$ & $0.9 \mathrm{c}$ & $0.24 \mathrm{a}$ & $16.3 \mathrm{a}$ \\
\hline$\overline{\text { C.V. }}$ & 26.67 & 29.19 & 8.93 & 16.96 & 17.22 & 33.92 & 12.41 \\
\hline
\end{tabular}

$\mathrm{H}+\mathrm{Al}$ - Potential acidity; P - Available phosphorus; OM - Organic matter; $\left(\mathrm{K}+, \mathrm{Ca}^{+2}\right.$ and $\left.\mathrm{Mg}^{+2}\right)$ - Potassium, Calcium and exchangeable Magnesium, respectively; SB - Sum of exchangeable bases; CEC (T) - Cationic exchange capacity to $\mathrm{pH} 7.0$; V - Based saturation index; PES - Percentage of exchangeable sodium; SAR - Sodium adsorption ratio; EC - Electrical conductivity of soil; PES - Percentage of exchangeable sodium; SAR - Sodium adsorption ratio; C.V. - coefficient of variation; ${ }^{\text {ns }}$ - not significant; Means followed by the same letter are not different from each other according to Scott-Knott's test at $5 \%$. 
corroborating the results obtained by Andrade Filho et al. (2013).

Oliveira et al. (2013) emphasize that these values are more specifically associated with the effect of sodium represented directly by the concentration of this element in soil ( $\mathrm{Na}$ in $\mathrm{cmol}_{\mathrm{c}} \mathrm{dm}^{-3}$ and PES). However, the continuous use of residuary waters over time may increase salinity, affect crop growth, development and yields (Varallo et al., 2010).

The organic matter $(\mathrm{OM})$ results are numerically higher than the initial condition of the soil $\left(\mathrm{C}_{0}\right)$, presenting higher values in treatments $\mathrm{E}_{50 \%}, \mathrm{E}_{75 \%}$ and $\mathrm{E}_{100 \%}$, probably due to the high organic matter concentration in this composition (Tables 1 and 3). Furthermore, the same behavior was observed by Coelho et al. (2011) working on sewage sludge application in banana trees. OM is important in cycling nutrients, it controls metal mobility and improves the soil structure, and is thus one of the main indicators of soil quality (Silva \& Mendonça, 2007).

The total pore volume (TPV) was not sensitive to the changes that occurred in soil applying the treated effluent (Table 4). Nevertheless, the pore distributions (macro and micropores) underwent significant changes. A tendency is noted to increased microporosity and diminished macroporosity with the growing increase of doses of sewage sludge composites applied (Table 4).

According to Souza et al. (2010) and Alves et al. (2015), in the soil total porosity and its subdivisions, the main interferences through handling wastewater would occur due to the suspended solids. Therefore, the relation with the highest values of macroporosity and lowest of microporosity obtained with the smaller doses of treated sewage effluent (TSE) are possibly related to the supply of organic substances that are part of TSE to the soil. However, the increase of TSE doses and consequent elevation of supply to the total suspended solids (TSS), besides the increase in electrical conductivity (Tables 1 and 3), can be associated with a possible dispersed clay eluviation, causing pore clogging and consequent macroporosity reduction as shown in the treatments $\mathrm{E}_{75 \%}$ and $\mathrm{E}_{100 \%}$ for clay dispersion. Since macroporosity is essential for soil aeration and plant development, it can be concluded that high doses of TSE had a negative effect on soil quality (Alves et al., 2015).

There was no significant effect of the treatments $\mathrm{E}_{0 \%}$, $\mathrm{E}_{25 \%}, \mathrm{E}_{50 \%}$ and $\mathrm{E}_{75 \%}$ on the soil bulk density (Ds) values. However, in treatment E100\% a decrease of Ds was observed (Table 4). According to the study by Ricci et al. (2010), these variables were not sensitive to the increasing doses of domestic sewage sludge applied to the soil. However, Maria et al. (2010) observed that the treated sewage sludge applied became less dense after it had been applied for five years, and there was a clear influence on the physical attributes of soil, in longer periods of application. In addition, in our study, the higher doses of treated domestic sewage effluent increased the soil organic matter content, while the experiment was conducted, probably due to the organic matter in its composition (Table 1) and the greater stress caused shown by the microbial metabolic quotient, which made decomposition difficult, explaining the reduction of soil bulk density (Tables 3, 4 and 5).

A reduction of hydraulic conductivity $\left(\mathrm{K}_{0}\right)$ was found compared to the initial condition of the soil $\left(\mathrm{C}_{0}\right)$. A higher $\mathrm{K}_{0}$ was found for doses $\mathrm{E}_{0 \%}, \mathrm{E}_{25 \%}, \mathrm{E}_{50 \%}$ and $\mathrm{E}_{75 \%}$, the result of the better aggregation of the soil and decreased macroporosity, influencing the infiltration rate of water (Vasconcelos et al., 2014)

The percentage of water-dispersed clay (WDC) presented higher values for $\mathrm{E}_{25 \%}, \mathrm{E}_{75 \%}$ and $\mathrm{E}_{100 \%}$. Clay dispersion is the result of a structural instability caused by the increased electric conductivity of soil using these treatments (Tables 5 and 6).

For the accumulated basal respiration of soil, evaluated in the $32^{\prime}$-day period there were no differences between the treatments (Table 5).

In soils under stressful conditions, a part of the energy used for microbial population growth is diverted to perform

Table 4: Physical alterations of the soil in response to the application of dilutions of residuary water from treated domestic sewage

\begin{tabular}{|c|c|c|c|c|c|c|}
\hline \multirow{2}{*}{ Treatment } & \multirow{2}{*}{$\begin{array}{c}\text { TPV } \\
\mathrm{cm}^{3} \mathrm{~cm}^{-3}\end{array}$} & Macro & Micro & \multirow{2}{*}{$\begin{array}{c}\text { Ds } \\
\mathrm{g} \mathrm{cm}^{-3}\end{array}$} & \multirow{2}{*}{$\frac{K_{0}}{\mathbf{m m ~ h}^{-1}}$} & \multirow{2}{*}{$\begin{array}{c}\text { WDC } \\
\%\end{array}$} \\
\hline & & \multicolumn{2}{|c|}{$\%$} & & & \\
\hline$\overline{\mathrm{E}_{0 \%}}$ & $32.75^{\mathrm{ns}}$ & $44.44 \mathrm{a}$ & $55.55 \mathrm{~b}$ & $1.81 \mathrm{a}$ & $461.9 \mathrm{a}$ & $11.9 \mathrm{~b}$ \\
\hline $\mathrm{E}_{25 \%}$ & 31.62 & $46.15 \mathrm{a}$ & $53.84 \mathrm{~b}$ & $1.81 \mathrm{a}$ & $596.5 \mathrm{a}$ & $13.1 \mathrm{a}$ \\
\hline $\mathrm{E}_{50 \%}$ & 30.62 & $36.61 \mathrm{~b}$ & $63.38 \mathrm{a}$ & $1.81 \mathrm{a}$ & $461.8 \mathrm{a}$ & $10.6 \mathrm{c}$ \\
\hline $\mathrm{E}_{75 \%}$ & 29.87 & $34.31 \mathrm{~b}$ & $65.68 \mathrm{a}$ & $1.78 \mathrm{a}$ & $429.8 \mathrm{a}$ & $14.2 \mathrm{a}$ \\
\hline $\mathrm{E}_{100 \%}$ & 29.00 & $32.72 \mathrm{~b}$ & $67.27 \mathrm{a}$ & $1.69 \mathrm{~b}$ & $174.7 \mathrm{~b}$ & $13.5 \mathrm{a}$ \\
\hline C.V. & 8.01 & 16.64 & 18.57 & 4.63 & 73.20 & 20.31 \\
\hline
\end{tabular}

TPV - total pore volume; Ds - Soil bulk density; K0 - hydraulic conductivity; WDC - water-dispersed clay; Ma or Mi - macro or microporosity, respectively; C.V. - coefficient of variation; ${ }^{\text {ns }}$ - not significant; Means followed by the same letter are not different from each other according to Scott-Knott's test at $5 \%$. 
Table 5: Microbiological changes of soil in response to the application of dilutions of residuary water from treated domestic sewage

\begin{tabular}{|c|c|c|c|}
\hline \multirow{2}{*}{ Treatment } & $\mathrm{C}-\mathrm{CO}_{2}$ & $\mathbf{C}_{\text {mic }}$ & $\mathrm{qCO}_{2}$ \\
\hline & ${\mathrm{mg} \mathrm{C}-\mathrm{CO}_{2}}_{\mathrm{kg} \text { de solo }}{ }^{-1} \mathrm{~h}^{-1}$ & $\mathrm{mg} \mathrm{C} \mathrm{Kg} \mathrm{solo}^{-1}$ & 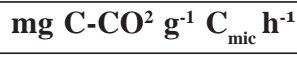 \\
\hline$\overline{\mathrm{E}_{0 \%}}$ & $0.79^{\text {ns }}$ & $280.41 \mathrm{~b}$ & $3.96 \mathrm{a}$ \\
\hline $\mathrm{E}_{25 \%}$ & 0.89 & $611.22 \mathrm{a}$ & $1.52 \mathrm{~b}$ \\
\hline $\mathrm{E}_{50 \%}$ & 1.07 & $234.94 \mathrm{~b}$ & $5.70 \mathrm{a}$ \\
\hline $\mathrm{E}_{75 \%}$ & 1.05 & $291.56 \mathrm{~b}$ & $3.83 \mathrm{a}$ \\
\hline $\mathrm{E}_{100 \%}$ & 0.98 & $284.80 \mathrm{~b}$ & $3.89 \mathrm{a}$ \\
\hline C.V. & 18.77 & 36.67 & 23.87 \\
\hline
\end{tabular}

$\mathrm{C}-\mathrm{CO}_{2}$ - soil basal respiration; $\mathrm{C}_{\text {mic }}$ - microbial biomass carbon; $\mathrm{qCO}_{2}$ - metabolic quotient; C.V. - coefficient of variation; ${ }^{\text {ns }}$ - not significant; Means followed by the same letter are not different from each other according to Scott-Knott's test at $5 \%$.

cell repair and maintenance. In this way part of the microbial carbon is lost during respiration (Matias et al., 2009). Thus, the application of TSE did not damage the soil microbiota.

During the evaluation period, the carbon of the microbial biomass increased further in the treatment with $\mathrm{E}_{25 \%}$ (Table 5), probably because the dilution provided more adequate doses of nutrients to the microbiota. On the other hand, the most concentrated treatments $\left(\mathrm{E}_{50 \%}\right.$, $\mathrm{E}_{75 \%}$ and $\mathrm{E}_{100 \%}$ ), despite a greater contribution of nutrients, did not differ from the control treatment performed with well water. Possibly this response is due to the contribution of organic matter and salts in these treatments (Table 1), increasing organic matter of the soil, but causing stress and preventing the growth of the microbial community, while the $\mathrm{E}_{0 \%}$ treatment did not contain organic matter or excess salts, which can be confirmed with the highest values for the metabolic quotient in these treatments (Table 5).

The metabolic quotient of soil $\left(\mathrm{qCO}_{2}\right)$ is an excellent microbial variable to be evaluated, since it allows the quick identification of some type of disturbance or stress in the soil (Quadro et al., 2011). The $\mathrm{E}_{25 \%}$ treatment presented the lowest value among the others indicating a lower stress rate for the microbial environment and the lowest oxidizable carbon consumption for maintenance, thus rendering its processes more efficient (Andrade et al., 2016).

\section{AKNOWLEDGEMENTS, FINANCIAL SUPPORT AND FULL DISCLOSURE}

The authors thank CAPES for the Master's degree scholarship for the first author.

\section{CONCLUSION}

The reuse of treated domestic sewage effluent to irrigate a castor bean crop changes the following chemical attributes of soil: $\mathrm{pH}$, exchangeable potassium, sum of exchangeable bases, available phosphorus, cationic exchange capacity to $\mathrm{pH} 7.0$, basic saturation index, percentage of exchangeable sodium, sodium adsorption ratio, electrical conductivity of soil, percentage of exchangeable sodium, sodium adsorption ratio and organic matter; Physical attributes: macroporosity, microporosity, soil bulk density, hydraulic conductivity and water dispersed clay and; Microbial attributes: microbial carbon and metabolic quotient. Furthermore, the larger proportions of effluent increased the concentrations of soluble salts in the soil indicating a risk of soil salinity.

Treated domestic sewage effluent at a proportion of $25 \%$ is a feasible alternative for soil irrigation, however it is necessary to monitor the possible changes in the soil attributes over successive crops. Proportions of 50, 75 and $100 \%$ of domestic sewage effluent studied are not recommended.

Microbial attributes can be used as a quick, good indicator of changes in soil quality by irrigation with treated domestic sewage effluent.

\section{REFERENCES}

Alves PFS, Santos SR, Kondo MK, Pegoraro RF \& Araújo ED (2015) Soil physical attributes in chemigated banana plantation with wastewater. Revista Engenharia Agrícola, 35:998-1008.

Andrade Filho J, Dias NS, Sousa Neto ON, Nascimento IB, Medeiros JF \& Cosme CR (2013) Atributos químicos de solo fertirrigado com água residuária no semiárido brasileiro. Irriga, 18:661-674.

Andrade LC, Andreazza R \& Camargo FAO (2016) Soil microbial activity under wastewater treatment plant sludge doses from an industrial landfill. Ciência Rural, 46:267-272.

APHA - American Public Health Association (1995) Standard methods for the examination of water and wastewater. $19^{\text {a }}$ ed. Washington, APHA. 1134p.

Araújo EA, Ker JC, Neves JCL \& La JL (2012) Qualidade do solo: conceitos, indicadores e avaliação. Revista Brasileira de Tecnologia Aplicada nas Ciências Agrárias, 05:187-206.

Barbosa EAA, Matsura EE, Santos LNS, Nazário AA, Gonçalves IZ \& Feitosa DRC (2018) Soil attributes and quality under treated domestic sewage irrigation in sugarcane. Revista Brasileira de Engenharia Agrícola e Ambiental, 22:137-142.

Barreto AN, Nascimento JJ, Medeiros EPD, Nóbrega JAD \& Bezerra JR (2013) Changes in chemical attributes of a Fluvent cultivated with castor bean and irrigated with wastewater. Revista Brasileira de Engenharia Agrícola e Ambiental, 17:480486 .

Rev. Ceres, Viçosa, v. 66, n.2, p. 077-084, mar/abr, 2019 
Braga MB \& Lima CEP (2014) Reuso de água na agricultura. Brasília, Embrapa. 200p.

CFSEMG - Comissão de Fertilidade do Solo do Estado de Minas Gerais (1999) Recomendação para uso de corretivos e fertilizantes em Minas Gerais. $5^{\text {a }}$ Aproximação. Viçosa, UFV. 359p.

Coelho HA, Grassi Filho H, Romeiro JCT, Pompermayer GV, Barbosa RD \& Lobo TF (2011) Desempenho agronômico do lodo de esgoto como fonte de nitrogênio em bananeiras. Agrarian, 04:172-181.

Costa VL, Maria IC, Camargo AO, Grego CR \& Melo LC (2014) Distribuição espacial de fósforo em Latossolo tratado com lodo de esgoto e adubação mineral. Revista Brasileira de Engenharia Agrícola e Ambiental, 18:287-293.

Costa ZVB, Gurgel MT, Costa LR, Alves SMC, Ferreira Neto M \& Batista RO (2014) Efeito da aplicação de esgoto doméstico primário na produção de milho no assentamento Milagres (Apodi-RN). Revista Ambiente \& Água, 09:737-751.

Embrapa - Empresa Brasileira de Pesquisa Agropecuária (2009) Manual de Análises Químicas de Solos, Plantas e Fertilizantes. $2^{a}$ Ed. Rio de Janeiro, Embrapa. 624p.

Erthal VJ, Ferreira PA, Matos AT \& Pereira OG (2010) Alterações físicas e químicas de um Argissolo pela aplicação de água residuária de bovinocultura. Revista Brasileira de Engenharia Agrícola e Ambiental, 14:467-477.

Feigin A, Ravina I \& Shalhevet J (1991) Irrigation with Treated Sewage Effluent: management for environmental protection. Berlin, Springer-Verlag. 224p.

Ferreira DF (2011) Sisvar: a computer statistical analysis system. Ciência e Agrotecnologia, 35:1039-1042.

Ferreira AS, Camargo FAO \& Vidor C (1999) Utilização de microondas na avaliação da biomassa microbiana do solo. Revista Brasileira de Ciência do Solo, 23:991-996.

Garcia GO, Martins Filho S, Reis EF, Moraes WB \& Nazário AA (2008) Alterações químicas de dois solos irrigados com água salina. Revista Ciência Agronômica, 39:07-18.

Gheyi HR, Dias NS \& Lacerda CF (2010) Manejo da salinidade na agricultura: Estudos básicos e aplicados. Fortaleza, INCT Sal. $472 \mathrm{p}$.

Gloaguen TV, Gonçalves RAB, Forti MC, Lucas Y \& Montes CR (2010) Irrigation with domestic wastewater: a multivariate analysis of main soil changes. Revista Brasileira de Ciência do Solo, 34:1427-1434.

Maria IC, Chiba MK, Costa A \& Berton RS (2010) Sewage sludge application to agricultural land as soil physical conditioner. Revista Brasileira de Ciência do Solo, 34:967-974.

Matias MCBS, Cavalcante SAA, Leite LFC \& Araújo ASF (2009) Biomassa microbiana e estoques de $\mathrm{C}$ e $\mathrm{N}$ do solo em diferentes sistemas de manejo, no Cerrado do Estado do Piauí. Agronomy, $31: 517-521$.

Molahoseini H (2014) Long-term effects of municipal wastewater irrigation on some properties of a semiarid region soil of Iran. International Journal of Scientific Engineering and Technology, 03:444-449.
Oliveira PC, Gloaguen TV, Gonçalves RA \& Santos DL (2013) Produção de moranga irrigada com esgoto doméstico tratado. Revista Brasileira de Engenharia Agrícola e Ambiental, 17:861867.

Pescod MB (1992) Wastewater treatment and use in agriculture. Rome, FAO. 125p.

Quadro MS, Castilhos DD, Castilhos RMV \& Vivian G (2011) Biomassa e atividade microbiana em solo acrescido de dejeto suíno. Current Agricultural Science and Technology, 17:85-93.

Ricci AB, Padovani VCR \& Paula Júnior DR (2010) Uso de lodo de esgoto estabilizado em um solo decapitado. Revista Brasileira de Ciência do Solo, 34:535-542.

Santos HG, Jacomine PKT, Anjos LHC, Oliveira VA, Lumbrelas JF, Coelho MR, Almeida JA, Araújo Filho JC, Oliveira JB \& Cunha TJF (2018) Sistema Brasileiro de Classificação de Solos. $5^{\text {a }}$ ed. Embrapa, Brasília. 353p.

Silva IR \& Mendonça ES (2007) Matéria Orgânica do Solo. In: Novais RF, Alvarez VVH, Barros NF, Fontes RLF, Cantarutti RB \& Neves JC (Ed.) Fertilidade do Solo. Viçosa, SBCS. p.275-374.

Simões K, Peixoto MFP, Almeida AT, Ledo CA, Peixoto CP \& Pereira FAC (2013) Água residuária de esgoto doméstico tratado na atividade microbiana do solo e crescimento da mamoneira. Revista Brasileira de Engenharia Agrícola e Ambiental, 17:518523.

Simonete MA, Kiehl JC, Andrade CA \& Teixeira CFA (2003) Efeito do lodo de esgoto em um Argissolo e no crescimento e nutrição de milho. Pesquisa Agropecuária Brasileira, 38:11871195 .

Soil Survey Staff (2014) Keys to Soil Taxonomy. 12 ${ }^{\text {th }}$ ed. Washington, USDA. 372p.

Souza NC, Mota SB, Bezerra FML, Aquino BF \& Santos AB (2010) Produtividade da mamona irrigada com esgoto doméstico tratado. Revista Brasileira de Engenharia Agrícola e Ambiental, $14: 478-484$

Souza JAA, Batista RO, Ramos MM \& Soares AA (2010) Alteração nas características físicas do solo decorrentes da aplicação de esgoto doméstico tratado. Acta Scientiarum. Technology, 32:361-366.

Tedesco MJ, Gianello C, Bissani CA, Bohnen H \& Wolkweiss SJ (1995) Análises de solo, plantas e outros materiais. $2^{\mathrm{a}}$ ed. Porto Alegre, UFRGS. 174p.

Vance ED, Brookes PC \& Jenkinson DS (1987) An extraction method for measuring soil microbial biomass C. Soil Biology \& Biochemistry, 19:703-707.

Varallo AC, Carvalho L, Santoro BL \& Souza CF (2010) Alterações nos atributos de um Latossolo Vermelho-amarelo irrigado com água de reúso. Revista Brasileira de Engenharia Agrícola e Ambiental, 14:372-377.

Vasconcelos RF, Souza ER, Cantalice JR \& Silva LS (2014) Qualidade física de Latossolo Amarelo de tabuleiros costeiros em diferentes sistemas de manejo da cana-de-açúcar. Revista Brasileira de Engenharia Agrícola e Ambiental, 18:381-386. 